\title{
1 Spatial patterns and environmental controls of particulate 2 organic carbon in surface waters in the conterminous \\ 3 \\ 4 \\ United States
}

5

\author{
Qichun Yang ${ }^{\mathrm{a}}$; Xuesong Zhang*a,b; Xingya Xu ${ }^{\mathrm{a}, \mathrm{c}}$; Ghassem R. Asrar ${ }^{\mathrm{a}}$; Richard A. Smith ${ }^{\mathrm{d}}$; \\ Jhih-Shyang Shih ${ }^{\mathrm{e}}$; Shuiwang Duan ${ }^{\mathrm{f}}$
}

a) Joint Global Change Research Institute, Pacific Northwest National Lab, College Park, MD 20740, USA

b) Great Lakes Bioenergy Research Center, Michigan State University, East Lansing, MI

$$
\text { 48824, USA }
$$

c) Department of Hydraulic Engineering, Tsinghua University, Beijing 100084, China

d) US Geological Survey, MS 413 National Center, Reston, VA 20192, USA

e) Resources For the Future, 1616 P St., NW Washington, DC 20036, USA

f) Earth System Science Interdisciplinary Center, University of Maryland, 5825 University Research Court, \#4049, College Park, MD 20740, USA \section{(1)}


24 Carbon cycling in inland waters has been identified as an important, but poorly constrained component of the global carbon cycle. In this study, we compile and analyze particulate organic carbon (POC) concentration data from 1145 U.S. Geological Survey (USGS) gauge stations to

27 investigate the spatial variability and environmental controls of POC concentration. We observe substantial spatial variability in POC concentration (1.43 \pm 2.56 mg C/ L, Mean \pm One Standard

29 Deviation), with the Upper Mississippi River basin and the Piedmont region in the eastern U.S. having the highest POC concentration. Further, we employ generalized linear models (GLMs) to analyze the impacts of sediment transport and algae growth as well as twenty-one other environmental factors on the POC variability. Suspended sediment and chlorophyll-a explain $26 \%$ and $17 \%$ of the variability in POC concentration, respectively. At the national level, the twenty-one environmental factors combined can explain ca. $40 \%$ of the spatial variance in POC concentration. At the national scale, urban area and soil clay content show significant negative correlations with POC concentration, whereas soil water content and soil bulk density correlate

37 positively with POC. In addition, total phosphorus concentration and dam density correlate positively with POC concentration. Furthermore, regional scale analyses reveal substantial variation in environmental controls of POC concentration across eighteen major water resource regions in the U.S. The POC concentration and associated environmental controls also vary non41 monotonically from headwaters to large rivers. These findings indicate complex interactions 42 among multiple factors in regulating POC concentration over different spatial scales and across 43 various sections of the river networks. This complexity, together with the large unexplained 44 uncertainty, highlights the need for considering non-linear interplays of multiple environmental 
45 factors and developing appropriate methodologies to track the transformation and transport of $46 \quad$ POC along the terrestrial-aquatic interfaces.

47 Key words: Particulate organic carbon; spatial variability; environmental control; uncertainty 48 


\section{Introduction}

50 Carbon cycling along the terrestrial-aquatic interfaces have been identified as an important, but

51 poorly constrained component of the global carbon cycle (Regnier et al., 2013; Butman et al.,

52 2016). In the Fifth Assessment Report of the International Panel on Climate Change (IPCC),

53 carbon export, burial, and outgassing from inland waters are highlighted as critical but

54 insufficiently investigated processes that may affect the global carbon budget (Ciais et al., 2013).

55 However, inclusion of these processes into regional and global carbon cycling investigations is

56 jeopardized by the significant uncertainties in the magnitude, variability, and environmental

57 controls of riverine carbon (Butman and Raymond, 2011; Regnier et al., 2013; Rodríguez-

58 Murillo et al., 2015).

59 Riverine carbon is mainly composed of three groups of carbon species including dissolved 60 organic carbon (DOC), particulate organic carbon (POC), and dissolved inorganic carbon (DIC)

61 (Cole et al., 2007). Synthesis of the global riverine carbon data suggests that magnitudes of

62 riverine POC (0.2 Pg C/year) and DOC (0.18-0.33 Pg C/year) fluxes are comparable at the global

63 scale (Cole et al., 2007; Galy et al., 2015). However, the underlying mechanisms controlling the

64 two species are distinct from each other and vary over different spatial scales (Zhang et al.,

65 2009). Therefore, it is necessary to explore the impacts of a wide range of environmental factors

66

on POC concentration to discover knowledge contributing to the explanation of carbon cycling

67 along the terrestrial-aquatic continuum.

Factors affecting POC in surface waters can be generally categorized into two groups based

69 on their influences on the supply and/or transport of POC. POC mainly originates from two

70 sources including erosion of soil organic carbon (Kirkels et al., 2014), and autochthonous

71 production (Hatten et al., 2010). Impacts of these two sources on riverine POC vary with 
72 distance from headwaters, land use types, and hydrological conditions. Soil erosion mobilizes as

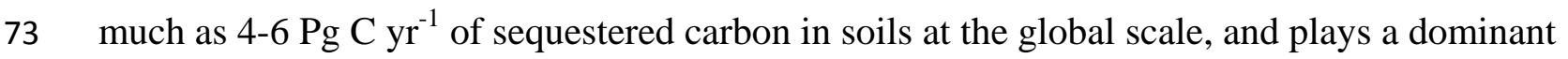

74 role in POC export (Galy et al., 2015). It was estimated that autochthonous production provides

75 approximately 8 to 28\% of POC in large rivers (Howarth et al., 1996; Veyssy et al., 1998). In

76 streams with enriched nutrients, algae growth could be the primary source of carbon input to

77 water bodies (Royer and David, 2005). Contributions of the two POC sources vary over different

78 temporal and spatial scales, resulting in significant variability in POC concentration.

79 Riverine POC is also controlled by transport-related factors. Carbon cycling is closely

80 coupled with water cycling since water movement from soils to rivers contributes to POC

81 transport (Kirkels et al., 2014). Rain drops provide energy and runoff for detaching and

82 mobilizing soil organic matter through erosion, especially during heavy rainfalls (Gomez et al.,

83 2003; Nearing et al., 2005). Meanwhile, intensive rainfalls and associated high streamflow

84 increase the capacity of rivers in carrying high concentrations of POC (Neitsch et al., 2009).

85 Remobilization of bottom sediment and bank erosion by floods also increase riverine POC

86 (Adams et al., 2015; Merritt et al., 2003; Smith et al., 2003).

87 Human activities have dramatically altered riverine POC through land conversions, damming, 88 and chemical fertilizer use (Butman et al., 2015;Kirkels et al., 2014; Syvitski et al., 2005; Zhou

89 et al., 2009). Land-use change influences riverine carbon cycling either by altering water cycling

90 or by changing the production of carbon leachates (Farley et al., 2005; Piao et al., 2007).

91 Agricultural activities enhance soil organic carbon (SOC) erosion through mobilizing organic

92 matter aggregates in top soils during tillage and irrigation (Kirkels et al., 2014). Dam

93 constructions have dramatically altered the natural flow regimes and resulted in high

94 sedimentation and burial of POC (Li et al., 2014). Excessive nutrient discharge to rivers and 
lakes from urban areas and agricultural lands stimulates autochthonous POC primary production, therefore increases concentration of river carbon (Rabalais, 2002).

Recent efforts have been devoted to unraveling the complex controls of riverine POC. However, most studies examining regional scale POC dynamics were mainly focused on quantifying the magnitude of POC export (Tian et al., 2015), but paid insufficient attention to exploring mechanisms governing POC (Schlunz and Schneider, 2000). Local scale investigations provide detailed descriptions of how riverine carbon dynamics are affected by input, in-stream decomposition, and deposition (Webster et al., 1999), and demonstrate contrasting results among different watersheds (Hope et al., 1994), reflecting the complex interplays of multiple processes in controlling the generation, transport and deposition of POC. Furthermore, it is uncertain whether the mechanisms identified through watershed-scale studies are applicable and transferable to broader scales that include complex climate conditions, land use types and geophysical settings (Hatten et al., 2010). The reported large uncertainties call for comprehensive analyses of factors influencing POC in surface waters.

Investigating how POC concentration in surface waters is affected by multiple environmental factors is a necessary and critical step towards better understanding of riverine POC fluxes. In this study, we compile POC concentration data from 1145 of the U.S. Geological Survey (USGS) gauge stations. Statistical analysis is employed to explore impacts of climate factors, hydrological conditions, soil properties, and anthropogenic activities on the spatial variability of POC concentration. The objectives are to: 1) characterize the spatial patterns of POC concentration across the U.S riverine systems; 2) identify key variables controlling riverine POC concentration over different spatial scales and river orders; and (3) provide insights into future investigations of riverine POC related carbon sources and sinks. 


\section{Method}

\subsection{Data compilation and statistical analysis}

[Figure 1]

We compiled field POC concentration data from 1145 USGS gauge stations (Figure 1) listed in the Geospatial Attributes of Gages for Evaluating Streamflow (GAGES-II) dataset (Falcone, 2011). The GAGES-II dataset provides geospatial attributes, such as climate conditions, geomorphological characteristics, and soil properties, for stations with long-term streamflow records ( $>20$ years). POC refers to carbon that cannot pass membrane filters with a 0.45 um pore size (https://water.usgs.gov/admin/memo/QW/qw00.08.html).We first checked the availability of POC concentration data for each GAGES-II station. Stations with available suspended organic matter (with USGS water quality parameter code of 00689), or paired total organic carbon (TOC, 00680) and dissolved organic carbon (DOC, 00681), were selected for this study. For the 1145 stations, we also collected total nitrogen (00600), total phosphorus (00665), suspended sediment (00530) and chlorophyll-a (70953) observations if they are available. Water samples of these stations were mainly collected from 1973 to 2015 . We downloaded these data from the USGS National Water Information System (NWIS) online database (http:/qwwebservices.usgs.gov/). For stations with paired TOC and DOC observations, but no POC, we calculated POC concentration by subtracting DOC from TOC. Since outliers may have significant impacts on statistical analysis and interpretation of environmental controls on POC, we performed a data quality control to identify outliers according to the USGS procedure (Aulenbach et al., 2007). We screened the POC observations to remove records outside three standard deviations of the 
140

141

142

143

144

145

146

147

148

149

150

151

152

153

154

155

156

157

158

159

160

161

162

mean (Gotway et al., 1994). Long-term average POC concentration from all valid samples at each site was calculated for the following analyses.

To analyze the influence of multiple environmental factors on riverine POC concentration, we obtained nineteen geospatial attributes for the drainage area of each station directly from the GAGES-II dataset, and two water quality variables from the NWIS water quality database. The values of the variables derived from the GAGES-II dataset represent the spatial average conditions of the drainage basin for each gauge station. Variables considered in this study include climate conditions (temperature, precipitation), hydrological factors (annual runoff), land cover information (cropland, forest, and wetlands), soil properties (soil texture, water content, bulk density, and soil organic carbon), topographic factors (slope, river order), dam density, and water quality (total nitrogen and total phosphorus). These variables were selected since they either have close connections with the hydrological cycle or with the carbon cycle, based on previous studies (Kirkels et al., 2014; Lal, 2003; Royer and David, 2005). To reduce the impacts of non-normal distribution on statistical analysis, we used log transformation to convert highlyskewed variables to approach symmetric distributions (More information is provided in the supporting document).

We divided all selected stations into 18 groups based on the delineation of the major U.S. water resources regions (Seaber et al., 1987), to account for regional variations in mechanisms controlling POC concentration. We also investigated impacts of environmental factors on POC concentration by river orders, by assigning all stations into four groups based on the river Strahler order, to explore the hierarchical patterns of POC.

We employed linear regression models to analyze the impacts of the selected environmental factors on POC concentration. First, we used bivariate regression analyses to check how the two 
163 POC sources (suspended sediment and algae) affect POC concentration. Then we tested the

164 linear correlation between POC concentration and each of the selected environmental factors to

165 demonstrate the complex environmental controls on POC. Next, a general linear model (GLM)

166 was used to quantify the interacting influences of the selected factors on POC concentration.

167 This model provides partial correlation estimates for each independent variable by eliminating

168 compounding impacts from other variables (Sweet and Grace-Martin, 2007). We applied the

169 GLM across all the stations to test how environmental factors affect POC concentration at the

170 national scale. Then, we applied the GLM analysis to each water resource region, as well as to

171 the four river-order groups. Variables with high collinearity were checked and removed from

172 these GLM analyses. Specifically, we checked the variance inflation factor (VIF) values of all

173 the variables for each GLM simulation. VIF is an index of multicollinearity among independent

174 variables in the GLM models. Variable with highest VIF value was removed until the VIF is less

175 than 10 for all independent variables. All the statistical analyses were conducted using the R

176 statistical software (http://www.R-project.org). We set the confidence level to 95\% $(P<0.05)$ to

177 detect statistically significant correlations. The GLM model equations are listed in the supporting

178 information file.

\section{3. Results}

$180 \quad 3.1$ Spatial patterns of POC concentration

181 POC concentration demonstrates significant spatial variability (Figure 1). Average POC

182 concentration of all stations is $1.43 \pm 2.56 \mathrm{mg} \mathrm{C/} \mathrm{L} \mathrm{(Mean} \pm$ One standard deviation).

183 Distribution of the POC concentration data is positively skewed, with $71.5 \%$ of all the

184 observations having a value lower than $1.3 \mathrm{mg} \mathrm{C}$ L. Stations with low POC concentration are

185 mainly located in the Eastern and Western coasts of the U.S. Stations with POC concentration 
over $3.35 \mathrm{mg}$ C/ L only account for $7.8 \%$ of all selected stations, and are mainly located in the upper Mississippi River basin and the Piedmont areas in the eastern U.S.

[Figure 2]

Water resources regions located in Missouri (region 2), the Upper Mississippi (Region 6), and the Lower Colorado (region 12), have higher average POC concentration than other regions (Figure 2). Specifically, average POC concentration in these three regions is 2.56, 2.24, and 2.55 mg C/ L, respectively. On the contrary, the New England region, the Mid-Atlantic region, and the Great Basin area have relatively lower average POC concentration, generally lower than 1mg C/ L. Lowest POC concentration is found in the California region (Region 8), with an average of $0.79 \mathrm{mg} \mathrm{C} / \mathrm{L}$.

\subsection{Contributions of suspended sediment and algae growth to POC concentration}

[Figure 3]

The mean suspended sediment and its standard deviation for all selected stations is $124 \pm 700$ mg / L, with low-concentration stations located in the Eastern and Western Coastal areas, and high-concentration stations located in the Central and Southwestern U.S. (Figures S1and S2 in supporting information). The mean Chlorophyll-a concentration and its standard deviation over all selected stations is $9.6 \pm 13.89 \mu \mathrm{g}$ / L (Figures S3 and S4), and stations with high chlorophylla concentration are mainly located in the Upper Mississippi River basin and Coastal areas in Northeastern U.S., Southern Florida, and California (> 17.6 pg / L). Correlation analysis indicates that POC concentration has positive correlations with both suspended sediment and chlorophyll-a. Specifically, suspended sediment accounts for approximately $26 \%$ of the POC variability, while chlorophyll-a concentration explains $17 \%$ of the POC variability (Figure 3). 3.3 POC concentration in relation to different environmental factors 
211 Most of the selected environmental factors have statistically significant correlation $(P<0.05)$

212 with POC concentration (Table 1). POC concentration tends to increase with drainage area.

213 Temperature and precipitation have contrasting impacts on POC concentration. POC

214 concentration tends to be high under warm temperatures and in dry areas, but low in cold and

215 wet regions. In line with the impacts of precipitation, runoff has negative impacts on POC

216 concentration. Both soil water and soil bulk density show positive correlations with POC

217 concentration. Multiple land covers contribute to the POC variability. Urban area and cropland

218 have positive correlations with POC concentration, whereas forest, shrub land, and barren area

219 are negatively correlated with POC concentration. Alterations to the natural regimes of river

220 discharge affect POC concentration. For example, dam density tends to boost POC concentration,

221 and excessive nutrient (nitrogen and phosphorus) inputs to surface waters have positive impacts

222 on POC concentration.

223 Although most of the selected variables have significant correlation with POC concentration,

224 each individual factor has a fairly low explanatory power for the POC variability. Only four

225 variables, including total phosphorus, total nitrogen, forest land cover, and soil water content,

226 each can explain more than $10 \%$ of the POC variability. Therefore, collective impacts from

227 multiple factors should be considered to better explain the spatial patterns of POC concentration.

The GLM model analyses suggest that POC concentration is affected synergistically by

231 multiple variables (Table 2, Figure 4). For the entire U.S., urban extent negatively affects POC

232 concentration $(P<0.01)$. Soil properties, such as soil water content $(P<0.01)$, bulk density $(P<$ 
$2330.01)$ and clay content $(P<0.05)$, show significant influences. POC concentration decreases with

234 soil clay content, whereas the other two soil variables have positive impacts. Total phosphorus in

235 water and dam density have positive impacts on POC concentration. No significant impacts were

236 detected for the other variables. At the national level, our multi-variate model explains up to $40 \%$

237 of the POC concentration variability.

238 Our regional scale analyses reveal significant variation in the mechanisms regulating POC

239 concentration across the 18 U.S. water resource regions (Table 2). For regions 4, 12, 14, and 16,

240 the GLM model fails to provide statistically significant correlation for POC concentration due to

241 insufficient observations. For regions 9 and 13, no variable shows significant impacts on POC.

242 Soil organic matter content has positive impacts in regions 2 and 8, but negatively affects POC

243 concentration in region 18. Region 3 is the only region where wetlands have positive impacts.

244 Temperature tends to increase POC in region 11. Runoff has a dilution effect in the California

245 region (region 8). In the Western U.S. (region 10), drainage area has positive impacts on POC.

246 Major land covers have either negative or insignificant $(P>0.05)$ impacts on POC. Specifically,

247 barren land negatively correlates with POC in region 18; urban extent tends to reduce POC

248 concentration in regions 1 and 11; shrub land has negative impacts in regions 8 and 11. Although

249 the selected soil properties (soil water, clay content, and soil bulk density) all significantly

250 correlate with POC at the national scale, they only exert significant influences in four of the 18

251 regions. Clay content negatively affects POC in region 7; soil water has positive impacts in

252 region 15; soil bulk density has positive impacts in regions 8 and 10. Percentage (length of first

253 order streams to total stream length in the drainage area of each station) of first-order rivers

254 correlates positively with POC concentration in region 3 and region 17. For regions in the

255 Eastern and Mid-eastern U.S, total phosphorus shows a positive correlation with POC. In 
256 addition, significant positive impacts $(P<0.05)$ of total phosphorus were also observed in

257 regions $2,3,4,6$, and $17(P<0.05)$. The significant influence of total nitrogen on POC occurs in

258 regions 6 and 18 . In region 6 , dam density is another variable having a significant correlation $(P$

$259<0.05)$ with POC.

260

261

262

263

264

265

266

267

268

269

270

271

272 only factor that has significant impacts $(P<0.05)$. For stations located at the $6^{\text {th }}$ and higher river

273 orders, POC concentration is negatively impacted by runoff $(P<0.05)$ and soil clay content $(P<$

274 0.05), but positively affected by soil organic matter $(P<0.05)$ and total phosphorus $(P<0.01)$.

\section{4. Discussion}

$276 \quad 4.1$ Spatial patterns of POC concentration

277 Overall, POC concentration demonstrates significant spatial variability with high POC

278 concentration occurring mainly in the Upper Mississippi River basin and the Piedmont area. 
279 Average POC concentration reported in this study $(1.42 \mathrm{mg} \mathrm{C} / \mathrm{L})$ is comparable to the previous 280 estimates (1.8 $\mathrm{mg} \mathrm{C/} \mathrm{L)} \mathrm{that} \mathrm{only} \mathrm{used} \mathrm{stations} \mathrm{located} \mathrm{close} \mathrm{to} \mathrm{the} \mathrm{outlets} \mathrm{of} \mathrm{major} \mathrm{U.S.} \mathrm{river}$ 281 basins (Stets and Striegl, 2012). High POC concentration in the Upper Mississippi River basin 282 may be induced by the high suspended sediment production in the Central U.S. (Smith et al., 283 2001), which is the home of the corn belt. High POC concentration in the Eastern U.S. may be

284 attributable to the high carbon load from soil erosion in the mountain areas (Dosskey and Bertsch, 285 1994).

286 Apart from the two regions with high POC concentration, we did not identify any apparent 287 patterns in POC concentration to be influenced by different climatic or hydrological conditions. 288 Our analyses demonstrate the complexity of the mechanisms regulating POC concentration. In 289 addition to the selected river basin properties, in-stream processes (aquatic primary production, 290 sediment deposition, and remobilization etc.) may have further complicated the spatial patterns 291 of POC concentration.

2924.2 Contribution of multiple sources to POC concentration

293 Detachment of soil organic matter during physical erosion and subsequent transport through 294 rivers has been identified as the primary control of POC export at the global scale (Galy et al., 295 2015). Our analyses corroborate the high correlation between suspended sediment and POC 296 concentration based on the detailed U.S. data. Soil erosion transports a large amount of POC 297 from land to surface waters (Smith et al., 2005). Soil erosion mobilizes $52 \mathrm{Tg} \mathrm{yr}^{-1}$ soil organic $^{2}$ 298 carbon in the conterminous U.S. and may play the dominant role in regulating riverine POC 299 cycling (Smith et al., 2001). In addition, the high correlation between suspended sediment and 300 POC concentration may also be attributable to sediment deposition and remobilization, which 301 affect POC dynamics in rivers (Drummond, 2014). 
Contribution of algae growth to riverine POC has not been well understood yet. Most previous investigations focused on large spatial scales indicated that aquatic primary production

304 had minor influence on riverine carbon (Cole et al., 2007). However, watershed-level studies 305 suggest that supplier of riverine carbon shifts from terrestrial sources to in-stream algal 306 production and from forest streams to agricultural rivers (Hagen et al., 2010). Our analyses imply 307 that chlorophyll-a has an explanatory power that is comparable in magnitude to suspended 308 sediment at the national scale, highlighting that algae growth may play a more important role in 309 determining riverine POC than previous studies have suggested (Duan et al., 2007; Findlay et al., 310 1991). As depicted in Figures 1 and 3, high chlorophyll-a concentration occurs coincidently with 311 high POC concentration in the Upper Mississippi River basin, illustrating that algae growth may 312 have significant impacts on POC in areas with intensive agricultural activities (Royer and David, 313 2005).

314 Although both suspended sediment and algae growth have significant impacts on POC 315 concentration, a large proportion of the POC variability is still not accounted for (Figures 3). 316 Other carbon sources, such as the allochthonous input through litter fall (Hagen et al., 2010), 317 particularly in headwaters, may need to be considered to explain the spatial patterns of POC. Due 318 to the dense plant canopy, litter fall is the primary source of carbon input for headwater streams 319 (Webster et al., 1997). It was estimated that plant litter input may account for roughly 69\% of the 320 carbon input to headwaters (Webster et al., 1997).

321 Contribution of litter fall and its interactions with other carbon sources may be responsible 322 for the non-monotonic patterns of POC from small streams to large rivers. Headwater streams 323 have typically high litter input and high respiration rates (Webster, 2007). In addition, high 324 sediment input from mountainous areas may also contribute to the elevated POC concentration in 
325 headwater rivers (Milliman and Syvitski, 1992). Reduced litter fall input may result in lower

326 average POC concentrations in the $3^{\text {rd }}$ order rivers than headwaters (Golladay, 1997). For large

327 rivers, in-stream production tends to play a more important role than riparian litter input

328 (Webster, 2007). In addition, input of carbon along with sediment deposition/remobilization may

329 further complicate the contribution of different carbon sources (Blair et al., 2004; Trimmer et al., 330 2012).

4.3 Environmental controls on POC concentration

332 Divergent correlations between POC concentration and the selected variables further illustrate 333 the complexity and nonlinearity in aquatic carbon cycling (Hanson et al., 2014), and suggest that 334 underlying processes regulating POC maybe spatial-scale specific (Sobek et al., 2007; Jackson 335 R. Webster, 2007). Since the partial correlation analysis (Table 2) measures impact of each 336 factor after removing the influence of other factors, our analysis of environmental controls on 337 POC concentration is mainly based on the GLM results.

338 At the national scale, soil properties show close correlations with POC concentration. 339 Significant impacts from soil water, soil density and soil clay content imply that movement of 340 carbon in soils plays an important role in affecting riverine POC concentration (Schlunz and 341 Schneider, 2000). Soil properties affect POC concentration mainly through controlling water 342 movement in soil (Price, 2011). Soils with high clay contents are characterized with low 343 effective porosity (Rawls et al., 1982), and movement of water and soil organic particles may be 344 jeopardized by the low connectivity. Similarly, soils with high clay content tend to have lower 345 bulk density and that is why the two variables have opposite correlations with POC concentration 346 (Dexter, 2004). Positive impacts of soil water content on POC concentration suggest that water 347 availability for mobilizing POC is important for POC leaching. 
Total phosphorus in surface waters is another important factor shaping the spatial patterns of POC concentration at the national scale. Since total phosphorus has a significant correlation with chlorophyll-a $(P<0.01)$, the positive correlation of total phosphorus with POC further confirms the important contribution of in-stream primary production to POC (Cole et al., 2007; Shih et al., 352 2010). In this study we find that phosphorus, rather than nitrogen, has a significant correlation 353 with POC concentration at the national scale. This result is in accordance with previous findings 354 that primary production in aquatic ecosystems is more limited by phosphorus than nitrogen 355 (Elser et al., 2007).

356 At the national scale, impacts of dam density should also be taken into consideration in 357 explaining the spatial variability of POC concentration. In contrast with studies which found dam 358 constructions substantially reduce riverine POC ( $\mathrm{Li}$ et al., 2014), our analyses point to a positive 359 correlation between dam density and POC. One possible explanation is that although reduced 360 flow velocity and sediment deposition following dam construction might reduce POC, algae 361 growth stimulated by dam construction may offset this reduction and increase the POC 362 concentration in surface waters (Friedl and Wüest, 2002).

363 Previous investigations indicate that land cover could explain a significant amount of 364 variability in lateral carbon movement, mainly because of differences in carbon storage and 365 hydrological conditions (Hope et al., 1994). Our analyses suggest that percentage of urban area 366 is the only land cover showing significant impacts on POC concentration at the national scale. 367 Discrepancies between this study and the SPAtially Referenced Regressions On Watershed 368 attributes (SPARROW) model investigations of total organic carbon (TOC) further illustrate that 369 riverine POC and DOC may be regulated by different process and thus need to be investigated 370 separately, and land covers may have less significant impacts on POC than DOC (Shih et al., 
371 2010). The negative impacts from urban area may be attributable to the special hydrological

372 processes and sediment transport in urban areas, but need to be further analyzed in case of non-

373 causative correlations (Howarth et al., 1991).

374 The remaining factors listed in table 2 affect POC mainly on regional scales. Although many

375 studies have underscored the importance of soil organic carbon on riverine carbon (Kalbitz et al., 376 2000), we find that SOC content only affects POC concentration positively in two water resource

377 regions. This finding is consistent with the fact that riverine POC only account for a small

378 fraction of the soil organic carbon pool, and POC generation may not be limited by soil organic

379 carbon stock (Bauer et al., 2013). Positive impacts of wetlands on riverine POC were only found

380 in region 3, indicating that high carbon storage in wetlands affect riverine POC only at the

381 regional scale. Other land cover types, such as shrub land, have similar, regional-specific impacts

382 as wetlands.

$383 \quad 4.4$ Interplays among multiple processes in regulating POC concentration

384 Concentration of POC in rivers reflects the interactive impacts of multiple processes during the 385 generation, transport, and transformation of POC (Hope et al., 1994). Impacts of the selected

386 factors on POC may be counteractive and their impacts may cancel each other out in determining

387 POC concentration. Identifying the counteractive processes is helpful for explaining the

388 variability in POC concentration across multiple spatial and hierarchical scales, and for

389 providing insights into developing process-based methodologies to track the dynamics of POC.

390 Although suspended sediment has significant impacts on POC (figure 3), our analysis does

391 not identify cropland area, which is usually associated with high soil erosion, as a significant

392 factor. Possible explanations responsible for the insignificant influence of erosion may lie in the

393 non-linear negative correlation between sediment concentration and POC concentration (Veyssy 
394 et al., 1998). At high sediment levels, POC content tends to be diluted by soil minerals (Galy et 395 al., 2015). In addition, suspended sediments only represent a small portion of the total eroded 396 sediment (Smith et al., 2001), and thus result in the complex impacts of erosion on riverine POC. 397 This result suggests that river channel's transport capacity may play an important role in POC 398 delivery in addition to upland soil erosion.

399 Deposition of suspended sediment at depositional sites substantially reduces total mobilized 400 particulate materials by soil erosion (Lal, 2003). For example, it was estimated that about $94 \%$

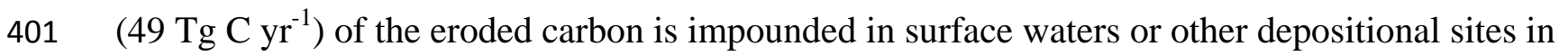
402 the U.S.(Smith et al., 2001; Stets and Striegl, 2012). Additionally, a large proportion of 403 suspended sediment in streams is contributed by river bed or bank erosion rather than terrestrial 404 sources (Blair et al., 2004), and partially explains the insignificant influence from cropland. 405 Therefore, elucidating the complex mechanisms that regulate POC concentration requires 406 improved understanding of POC production, mobilization, and transport along the coupled 407 terrestrial-aquatic continuum. Our findings and explanations should be further tested in the future 408 to explore the complex interplays among soil erosion, sediment deposition/mobilization, and 409 carbon cycling.

410 Previous investigations have suggested that rainfall controls the detachment of soil organic 411 matter and transport of sediment (Lufafa et al., 2003), and storm flows disproportionally 412 contribute to lateral carbon export (Smith et al., 2003). In contrast, our analysis suggests that 413 runoff mainly play negative roles due to the dilution of POC concentration (Findlay et al., 1991). 414 In addition, regions receiving heavy rainfalls also tend to have dense vegetation covers, which 415 protect soils from erosion (Durán Zuazo and Rodríguez Pleguezuelo, 2008). Note that in this 416 study we focus primarily on the relationship between long-term average runoff and POC 
417 concentration, instead of seasonal variability of POC and associated processes. Since

418 hydrological and biological processes both have significant seasonal variability (Bianchi et al.,

419 2004), how these processes regulate POC concentration over finer temporal scales awaits further

420 exploration to improve our understanding of hydrological controls on riverine POC.

421 Impacts of dam construction on sedimentation and burial of organic carbon have been widely

422 investigated (Cole et al., 2007). Due to the reduced flow velocity, dams and reservoirs can trap

423 up to $100 \%$ of the sediment transported from upstream rivers (Toniolo et al., 2004). It was

424 estimated that burial of carbon in reservoirs is higher than that by all natural waters (Cole et al.,

425 2007). However, results of our correlation analyses indicate that dam density has a positive

426 impact on POC concentration. This finding does not necessarily imply that dam has no impacts

427 on sedimentation. Other processes associated with dam construction, such as changes in flow

428 regime that promote algae growth, may increase POC concentration. Understanding impacts of

429 these processes requires explicit representations of dam related alteration of hydrologic,

430 biological, and biogeochemical processes in watershed models.

$431 \quad 4.5$ Uncertainties in modeling riverine POC concentration

432 The primary purpose of the statistical modeling analysis is to identify factors that have

433 significant linear impacts on POC. These factors are also expected to be related to important

434 physical processes regulating POC concentration, thereby informing future modeling efforts.

435 Notably, a large portion (60\%) of the variability in POC concentration is unexplained by the

436 selected variables and linear models, indicating that additional factors and nonlinear processes

437 should be considered in order to better represent the complexity of riverine POC modeling..

438 First, most of the selected watershed attributes have indirect impacts on POC concentration

439 in streams. Although terrestrial sources provide large amounts of mobilized POC, only a small 
440 portion (6\%) is transported to coastal waters (Smith et al., 2001), indicating significant controls

441 during riverine transport. As a result, including instream factors, such as flow velocity and water

442 residence time, is expected to further constrain the uncertainties in explaining POC concentration

443 (Blair et al., 2004; Prosser and Rustomji, 2000).

444 Second, linear regression models have limited powers to simulated complex biogeochemical

445 processes. Cycling of POC along the terrestrial-aquatic interfaces is controlled by a plethora of

446 interconnected processes (Hope et al., 1994). Our results highlight the necessity of developing

447 and employing process-based models, which consider the key factors and processes to further

448 improve POC modeling.

449 Finally, quality of the observational data also affects the analysis results. We primarily

450 focused on the long-term patterns of POC concentration and associated river basin attributes

451 mainly due to the limited availability of observational data, while POC and other water quality

452 variables, such as total phosphorus and total nitrogen, have pronounced seasonal and interannual

453 variability. Furthermore, watershed attributes, such as percentage of varying land covers, change

454 over time. Using the long-term averages, especially for variables collected in different years,

455 may have introduced uncertainties and caused non-causative correlations in our statistical

456 analysis. To reduce such uncertainties, more extensive field experimental exercises with the aim

457 of collecting concurrent environmental data over large regions are required in the future.

458 5. Conclusion

459 In this study, we investigate the spatial variability and environmental controls of POC

460 concentration across the conterminous U.S. and 18 major water resource regions. POC

461 concentration demonstrates significant spatial variability, with the Upper Mississippi River basin 
462 and the Piedmont region in the eastern U.S. having the highest POC concentration. Both algae 463 growth and sediment transport are important sources of riverine POC.

464 In this study, generalized multi-variate linear models can explain ca. $40 \%$ of the spatial 465 variance of POC concentration over 1145 USGS gauge stations. At the national scale, factors 466 that have significant impacts on POC include soil properties, drainage area, total phosphorus 467 concentration, and dam density. Our further analyses at the regional scale show substantial 468 variation in environmental controls of POC concentration across the 18 major water resource 469 regions in the U.S. In addition, POC concentration and associated environmental controls also 470 vary non-monotonically with river orders. These findings indicate complex interactions among

471 multiple factors regulating POC production over different spatial scales and across various

472 components of the river networks. This complexity, along with the large unexplained uncertainty, 473 calls for the development of process-based, non-linear methodologies that consider coupled 474 terrestrial-aquatic processes regulating supply, removal, and transformation of POC in order to 475 better constrain this carbon flux.

476

477

478

479

480

481

482 
486 Acknowledgements:

487 We sincerely appreciate the valuable comments provided by the anonymous reviewers. This

488 work was funded by the NASA New Investigator Award (NIP, NNH13ZDA001N) and

489 Terrestrial Ecology Program (NNH12AU03I) as part of the North American Carbon Program,

490 and the DOE Great Lakes Bioenergy Research Center (DOE BER Office of Science DE-FC02-

491 07ER64494, DOE BER Office of Science KP1601050, DOE EERE OBP 20469-19145). 


\section{References:}

Adams, J.L., Tipping, E., Bryant, C.L., Helliwell, R.C., Toberman, H., Quinton, J., 2015. Aged riverine particulate organic carbon in four UK catchments. Sci. Total Environ. 536, 648654. doi:10.1016/j.scitotenv.2015.06.141

Aquilina, L., Poszwa, A., Walter, C., Vergnaud, V., Pierson-Wickmann, A.C., Ruiz, L., 2012. Long-term effects of high nitrogen loads on cation and carbon riverine export in agricultural catchments. Environ. Sci. Technol. 46, 9447-9455. doi:10.1021/es301715t

Aulenbach, B.T., Buxton, H.T., Battaglin, W.A., Coupe, R.H., 2007. Streamflow and nutrient fluxes of the Mississippi-Atchafalaya River Basin and subbasins for the period of record through 2005: U.S. Geological Survey Open-File Report 2007-1080, http://toxics.usgs.gov/pubs/of-2007-1080/index.html

Bauer, J.E., Cai, W.-J., Raymond, P.A, Bianchi, T.S., Hopkinson, C.S., Regnier, P. A.G., 2013. The changing carbon cycle of the coastal ocean. Nature 504, 61-70. doi:10.1038/nature12857

Bianchi, T.S., Filley, T., Dria, K., Hatcher, P.G., 2004. Temporal variability in sources of dissolved organic carbon in the lower Mississippi river. Geochim. Cosmochim. Acta 68, 959-967. doi:10.1016/j.gca.2003.07.011

Blair, N.E., Leithold, E.L., Aller, R.C., 2004. From bedrock to burial: The evolution of particulate organic carbon across coupled watershed-continental margin systems. Mar. Chem. 92, 141-156. doi:10.1029/2002JC001467

Butman, D., Raymond, P., 2011. Significant efflux of carbon dioxide from streams and rivers in the US. Nat. Geosci. 1-32. doi:DOI: 10.1038/NGEO1294

Butman, D.E., Wilson, H.F., Barnes, R.T., Xenopoulos, M.A., Raymond, P.A., 2015. Increased mobilization of aged carbon to rivers by human disturbance. Nat. Geosci. 8, 112-116. doi:10.1038/NGEO2322

Butman, D., Stackpoole, S., Stets, E., Mcdonald, C.P., Clow, D.W., Striegl, R.G., 2016. Aquatic carbon cycling in the conterminous United States and implications for terrestrial carbon accounting. Proc. Natl. Acad. Sci. 113, 58-63. doi:10.1073/pnas.1512651112

Ciais, P., Sabine, C., Bala, G., Bopp, L., Brovkin, V., Canadell, J., Chhabra, A., DeFries, R., Galloway, J., Heimann, M., Jones, C., Quéré, C. Le, Myneni, R.B., Piao, S., Thornton, P., France, P.C., Willem, J., Friedlingstein, P., Munhoven, G., 2013. 2013: Carbon and Other Biogeochemical Cycles. Clim. Chang. 2013 Phys. Sci. Basis. Contrib. Work. Gr. I to Fifth Assess. Rep. Intergov. Panel Clim. Chang. 465-570. doi:10.1017/CBO9781107415324.015

Cole, J.J., Prairie, Y.T., Caraco, N.F., McDowell, W.H., Tranvik, L.J., Striegl, R.G., Duarte, 
C.M., Kortelainen, P., Downing, J.A., Middelburg, J.J., Melack, J., 2007. Plumbing the global carbon cycle: Integrating inland waters into the terrestrial carbon budget. Ecosystems 10, 172-185. doi:10.1007/s10021-006-9013-8

Dexter, A.R., 2004. Soil physical quality Part I. Theory, effects of soil texture, density, and organic mailer, and effects on root growth. Geoderma 120, 201-214. doi:10.1016/j.geodermaa.2003.09.005

Dosskey, M., Bertsch, P., 1994. Forest sources and pathways of organic matter transport to a blackwater stream: a hydrologic approach. Biogeochemistry 24. doi:10.1007/BF00001304

Drummond, J., 2014. Stochastic modeling of fine particulate organic carbon dynamics in rivers. Water Resour. 1-16. doi:10.1002/2013WR014665.Received

Duan, S., Bianchi, T.S., Sampere, T.P., 2007. Temporal variability in the composition and abundance of terrestrially-derived dissolved organic matter in the lower Mississippi and Pearl Rivers. Mar. Chem. 103, 172-184. doi:10.1016/j.marchem.2006.07.003

Durán Zuazo, V.H., Rodríguez Pleguezuelo, C.R., 2008. Soil-erosion and runoff prevention by plant covers. A review. Agron. Sustain. Dev. 28, 65-86. doi:10.1051/agro:2007062

Elser, J.J., Bracken, M.E.S., Cleland, E.E., Gruner, D.S., Harpole, W.S., Hillebrand, H., Ngai, J.T., Seabloom, E.W., Shurin, J.B., Smith, J.E., 2007. Global analysis of nitrogen and phosphorus limitation of primary producers in freshwater, marine and terrestrial ecosystems. Ecol. Lett. 10, 1135-42. doi:10.1111/j.1461-0248.2007.01113.x

Falcone, J.A., 2011. GAGES-II, Geospatial Attributes of Gages for Evaluating Streamflow.

Farley, K.A., Jobbagy, E.G., Jackson, R.B., 2005. Effects of afforestation on water yield: a global synthesis with implications for policy. Glob. Chang. Biol. 11, 1565-1576. doi:10.1111/j.1365-2486.2005.01011.x

Findlay, S., Pace, M., Lints, D., 1991. Variability and Transport of Suspended Sediment , Particulate and Dissolved Organic Carbon in the Tidal Freshwater Hudson River. Biogeochemistry 12, 149-169.

Friedl, G., Wüest, A., 2002. Disrupting biogeochemical cycles - Consequences of damming. Aquat. Sci. 64, 55-65.

Galy, V., Peucker-Ehrenbrink, B., Eglinton, T., 2015. Global carbon export from the terrestrial biosphere controlled by erosion. Nature 521, 204-207. doi:10.1038/nature14400

Golladay, S.W., 1997. Suspended particulate organic matter concentration and export in streams. J. North Am. Benthol. Soc. 16, 122-130.

Gomez, B., 2003. Production, storage, and output of particulate organic carbon: Waipaoa River 
basin, New Zealand. Water Resour. Res. 39. doi:10.1029/2002WR001619

Gotway, C.A., Helsel, D.R., Hirsch, R.M., 1994. Statistical Methods in Water Resources. Technometrics 36, 323. doi:10.2307/1269385

Hagen, E.M., McTammany, M.E., Webster, J.R., Benfield, E.F., 2010. Shifts in allochthonous input and autochthonous produciton in streams along an agricultural land-use gradient. Hydrobiologia 655, 61-77. doi:10.1007/s10750-010-0404-7

Hanson, P.C., Pace, M.L., Carpenter, S.R., Cole, J.J., Stanley, E.H., 2014. Integrating landscape carbon cycling: Research needs for resolving organic carbon budgets of lakes. Ecosystems 363-375. doi:10.1007/s10021-014-9826-9

Hatten, J.A., Goñi, M.A., Wheatcroft, R.A., 2010. Chemical characteristics of particulate organic matter from a small, mountainous river system in the Oregon Coast Range, USA. Biogeochemistry 107, 43-66. doi:10.1007/s10533-010-9529-z

Hope, D., Billett, M.F., Cresser, M.S., 1994. A review of the export of carbon in river water:fluxes and processes. Environ. Pollut. 84, 301-324.

Howarth, R., Fruci, J.R., Sherman, D., 1991. Inputs of sediment and carbon to an estuarine ecosystem : Influence of land use. Ecol. Appl. 1, 27-39.

Howarth, R.W., Schneider, R., Swaney, D., 1996. Metabolism and organic carbon fluxes in the tidal freshwater Hudson River. Estuaries 19, 848-865.

Hruska, J., Krám, P., McDowell, W.H., Oulehle, F., 2009. Increased dissolved organic carbon (DOC) in Central European streams is driven by reductions in ionic strength rather than climate change or decreasing acidity. Environ. Sci. Technol. 43, 4320-6.

Kalbitz, K., Solinger, S., Park, J.-H., Michalzik, B., Matzner, E., 2000. Controls on the dynamics of dissolved organic matter in soils: a review. Soil Sci. 165, 277-304.

Kirkels, F.M.S.A., Cammeraat, L.H., Kuhn, N.J., 2014. The fate of soil organic carbon upon erosion, transport and deposition in agricultural landscapes - A review of different concepts. Geomorphology 226, 94-105. doi:10.1016/j.geomorph.2014.07.023

Lal, R., 2003. Soil erosion and the global carbon budget. Environ. Int. 29, 437-450. doi:10.1016/S0160-4120(02)00192-7

Li, G., Wang, X.T., Yang, Z., Mao, C., West, A.J., Ji, J., 2014. Dam-triggered organic carbon sequestration makes the Changjiang (Yangtze) river basin (China) a significant carbon sink 1-15. doi:10.1002/2014JG002646.Received

Lufafa, A., Tenywa, M.M., Isabirye, M., Majaliwa, M.J.G., Woomer, P.L., 2003. Prediction of soil erosion in a Lake Victoria basin catchment using a GIS-based Universal Soil Loss 
model. Agric. Syst. 76, 883-894. doi:10.1016/S0308-521X(02)00012-4

Marín-Spiotta, E., Gruley, K.E., Crawford, J., Atkinson, E.E., Miesel, J.R., Greene, S., CardonaCorrea, C., Spencer, R.G.M., 2014. Paradigm shifts in soil organic matter research affect interpretations of aquatic carbon cycling: Transcending disciplinary and ecosystem boundaries. Biogeochemistry 117, 279-297. doi:10.1007/s10533-013-9949-7

Merritt, W.S., Letcher, R.A., Jakeman, A. J., 2003. A review of erosion and sediment transport models. Environ. Model. Softw. 18, 761-799. doi:10.1016/S1364-8152(03)00078-1

Milliman, J.D., Syvitski, J.P.M., 1992. Geomorphic/Tectonic Control of Sediment Discharge to the Ocean: The Importance of Small Mountainous Rivers. J. Geol. 100, 525-544. doi:10.1086/629606

Nearing, M.A., Jetten, V., Baffaut, C., Cerdan, O., Couturier, A., Hernandez, M., Le Bissonnais, Y., Nichols, M.H., Nunes, J.P., Renschler, C.S., Souchère, V., van Oost, K., 2005. Modeling response of soil erosion and runoff to changes in precipitation and cover. Catena 61, 131-154. doi:10.1016/j.catena.2005.03.007

Neitsch, S.L., Arnold, J.G., Kiniry, J. IR., Willianms, J.R., 2009. Soil \& Water Assessment Tool Theoretical Documentation Version 2009. Texas A\&M University System, College Station, Texas.

Piao, S., Friedlingstein, P., Ciais, P., de Noblet-Ducoudré, N., Labat, D., Zaehle, S., 2007. Changes in climate and land use have a larger direct impact than rising $\mathrm{CO} 2$ on global river runoff trends. Proc. Natl. Acad. Sci. U. S. A. 104, 15242-7. doi:10.1073/pnas.0707213104

Prosser, I.P., Rustomji, P., 2000. Sediment transport capacity relations for overland flow. Prog. Phys. Geogr. 24, 79-93. doi:10.1191/030913300760564698

Price, K., 2011. Effects of watershed topography, soils, land use, and climate on baseflow hydrology in humid regions: A review. Prog. Phys. Geogr. 35, 465-492. doi:10.1177/0309133311402714

Quinton, J.N., Catt, J.A., Wood, G.A., Steer, J., 2006. Soil carbon losses by water erosion: Experimentation and modeling at field and national scales in the UK. Agric. Ecosyst. Environ. 112, 87-102. doi:10.1016/j.agee.2005.07.005

Rabalais, N.N., 2002. Nitrogen in aquatic ecosystems. Ambio 31, 102-12.

Rawls, W.J., Brakensiek, D.L., Saxton, K.E., 1982. Estimation of Soil Water Properties. Trans. ASAE.

Regnier, P., Friedlingstein, P., Ciais, P., Mackenzie, F.T., Gruber, N., Janssens, I. a., Laruelle, G.G., Lauerwald, R., Luyssaert, S., Andersson, A.J., Arndt, S., Arnosti, C., Borges, A. V., Dale, A.W., Gallego-Sala, A., Goddéris, Y., Goossens, N., Hartmann, J., Heinze, C., Ilyina, 
T., Joos, F., LaRowe, D.E., Leifeld, J., Meysman, F.J.R., Munhoven, G., Raymond, P., Spahni, R., Suntharalingam, P., Thullner, M., 2013. Anthropogenic perturbation of the carbon fluxes from land to ocean. Nat. Geosci. 6, 597-607. doi:10.1038/ngeo1830

Rodríguez-Murillo, J.C., Zobrist, J., Filella, M., 2015. Temporal trends in organic carbon content in the main Swiss rivers, 1974-2010. Sci. Total Environ. 502, 206-217. doi:10.1016/j.scitotenv.2014.08.096

Royer, T. V., David, M.B., 2005. Export of dissolved organic carbon from agricultural streams in Illinois, USA. Aquat. Sci. 67, 465-471. doi:10.1007/s00027-005-0781-6

Seaber, P. R. , Kapinos, F. P. \& Knapp, G. L. Hydrologic Units Maps (U. S. Geological Survey Water Supply Paper 2294, Reston, Virginia, 1987).

Schlunz, B., Schneider, R.R., 2000. Transport of terrestrial organic carbon to the oceans by rivers: re-estimating flux- and burial rates. Int. J. Earth Sci. 88, 599-606. doi:10.1007/s005310050290

Shih, B.J., Alexander, R.B., Smith, R.A., Boyer, E.W., Schwarz, G.E., Chung, S., 2010. An initial SPARROW model of land use and in-stream controls on total organic carbon in streams of the conterminous United States: U.S. Geological Survey Open-File Report 20101276, 22 p., available at http://pubs.usgs.gov/of/2010/1276.

Smith, B.P.G., Naden, P.S., Leeks, G.J.L., Wass, P.D., 2003. The influence of storm events on fine sediment transport, erosion and deposition within a reach of the River Swale, Yorkshire, UK. Sci. Total Environ. 314-316, 451-474. doi:10.1016/S0048-9697(03)000688

Smith, S., Renwick, W.H., Buddemeier, R.W., Crossland, C.J., 2001. Budgets of soil erosion and deposition for sediments and sedimentary organic carbon across the posited across the United States. Global Biogeochem. Cycles 15, 697-707.

Smith, S.V., Sleezer, R.O., Renwick, W.H., Buddemeier, R.W., 2005. Fates of eroded soil organic carbon: Mississippi Basin case study. Ecol. Appl. 15, 1929-1940. doi:10.1890/050073

Sobek, S., Tranvik, L.J., Prairie, Y.T., Kortelainen, P., Cole, J.J., 2007. Patterns and regulation of dissolved organic carbon: An analysis of 7,500 widely distributed lakes. Limnol. Oceanogr. 52, 1208-1219. doi:10.4319/lo.2007.52.3.1208

Stets, E.G., Striegl, R.G., 2012. Carbon export by rivers draining the conterminous United States. Inl. Waters 2, 177-184. doi:10.5268/IW-2.4.510

Sweet, S., Grace-Martin, K., 2012. Chapter 7- Modeling Relationships of Multiple Variables with Linear Regression in Data Analysis with SPSS: A First Course in Applied Statistics, 
4th Edition. Pearson.

Syvitski, J.P.M., Vörösmarty, C.J., Kettner, A.J., Green, P., 2005. Impact of humans on the flux of terrestrial sediment to the global coastal ocean. Science 308, 376-380.

doi:10.1126/science.1109454

Tian, H., Yang, Q., Najjar, R., Ren, W., Friedrichs, M.A. M., Hopkinson, C.S., Pan, S., 2015. Anthropogenic and climatic influences on carbon fluxes from eastern North America to the Atlantic Ocean: A process-based modeling study. J. Geophys. Res. Biogeosciences n/a-n/a. doi:10.1002/2014JG002760

Toniolo, H., Harff, P., Marr, J., Paola, C., Parker, G., 2004. Experiments on Reworking by Successive Unconfined Subaqueous and Subaerial Muddy Debris Flows. J. Hydraul. Eng. 130, 38-48. doi:10.1061/(ASCE)0733-9429(2004)130:1(38)

Trimmer, M., Grey, J., Heppell, C.M., Hildrew, A.G., Lansdown, K., Stahl, H., Yvon-Durocher, G., 2012. River bed carbon and nitrogen cycling: state of play and some new directions. Sci. Total Environ. 434, 143-58. doi:10.1016/j.scitotenv.2011.10.074

Veyssy, E., Etcheber, H., Lin, R.G., Buat-Menard, P., Maneux, E., 1998. Seasonal variation and origin of Particulate Organic Carbon in the lower Garonne River at La Reole (southwestern France). Hydrobiologia 391, 113-126. doi:10.1023/A:1003520907962

Webster, J.R., 2007. Spiraling down the river continuum : stream ecology and the U-shaped curve. J. Am. Benthol. Soc. 26, 375-389.

Webster, J.R., 2007. Spiraling down the river continuum: stream ecology and the U-shaped curve. J. North Am. Benthol. Soc. 26, 375-389. doi:10.1899/06-095.1

Webster, J.R., Benfield, E.F., Ehrman, T.P., Schaeffer, M.A., Tank, J.L., Hutchens, J.J., D’Angelo, D.J., 1999. What happens to allochthonous material that falls into streams? A synthesis of new and published information from Coweeta. Freshw. Biol. 41, 687-705. doi:10.1046/j.1365-2427.1999.00409.x

Webster, J.R., Meyer, J.L., Wallace, J.B., Benfield, E.F., 1997. Organic matter dynamics in Hugh White Creak, Coweeta Hydrologica Laboratory, North Carolina, USA. Journal of the North American Benthological Society.

Zhang, S., Lu, X.X., Sun, H., Han, J., Higgitt, D.L., 2009. Geochemical characteristics and fluxes of organic carbon in a human-disturbed mountainous river (the Luodingjiang River) of the Zhujiang (Pearl River), China. Sci. Total Environ. 407, 815-825. doi:10.1016/j.scitotenv.2008.09.022

Zhou, G., Bi, Y., Zhao, X., Chen, L., Hu, Z., 2009. Algal growth potential and nutrient limitation in spring in Three-Gorges Reservoir, China. Fresenius Environ. Bull. 18, 1642-1647. 


\section{Tables}

Table 1. Bivariate analysis of environmental impacts on POC concentration

\begin{tabular}{|c|c|c|c|c|c|}
\hline & F-value & Slope & $P$-value & Ad- $^{2}$ & $\begin{array}{l}\text { Y- } \\
\text { Intercept }\end{array}$ \\
\hline POC $^{\mathrm{T}}$ versus total phosphorus ${ }^{\mathrm{T}}$ & 495.6 & 0.454 & $0.000^{* *}$ & 0.306 & 0.886 \\
\hline POC $^{\mathrm{T}}$ versus total nitrogen ${ }^{\mathrm{T}}$ & 331.6 & 0.522 & $0.000 * *$ & 0.231 & -0.275 \\
\hline POC $^{\mathrm{T}}$ versus total forest & 165.4 & -0.012 & $0.000 * *$ & 0.126 & 0.287 \\
\hline POC $^{\mathrm{T}}$ versus soil water ${ }^{\mathrm{T}}$ & 162 & 1.405 & $0.000^{* *}$ & 0.123 & 2.723 \\
\hline POC $^{\mathrm{T}}$ versus cropland ${ }^{\mathrm{T}}$ & 101.4 & 0.100 & $0.000 * *$ & 0.092 & -0.210 \\
\hline POC $^{\mathrm{T}}$ versus runoff ${ }^{\mathrm{T}}$ & 107.5 & -0.284 & $0.000 * *$ & 0.086 & 1.410 \\
\hline POC $^{\mathrm{T}}$ versus soil sand & 93.54 & -0.468 & $0.000^{* *}$ & 0.075 & 1.450 \\
\hline POC $^{\mathrm{T}}$ versus slope ${ }^{\mathrm{T}}$ & 71.94 & -0.151 & $0.000 * *$ & 0.058 & 0.038 \\
\hline POC $^{\mathrm{T}}$ versus soil clay & 57.07 & 0.021 & $0.000^{* *}$ & 0.048 & -0.664 \\
\hline POC $^{\mathrm{T}}$ versus precipitation ${ }^{\mathrm{T}}$ & 53.55 & -0.472 & $0.000^{* *}$ & 0.045 & 1.968 \\
\hline POC $^{\mathrm{T}}$ versus shrub land ${ }^{\mathrm{T}}$ & 48.61 & -0.075 & $0.000^{* *}$ & 0.041 & -0.140 \\
\hline $\mathrm{POC}^{\mathrm{T}}$ versus soil bulk density ${ }^{\mathrm{T}}$ & 35.77 & 1.932 & $0.000^{* *}$ & 0.030 & -2.903 \\
\hline POC $^{\mathrm{T}}$ versus barren surface ${ }^{\mathrm{T}}$ & 34.35 & -0.091 & $0.000^{* *}$ & 0.030 & -0.331 \\
\hline POC $^{\mathrm{T}}$ versus urban area ${ }^{\mathrm{T}}$ & 22.14 & 0.065 & $0.000 * *$ & 0.019 & -0.156 \\
\hline POC $^{\mathrm{T}}$ versus drainage area ${ }^{\mathrm{T}}$ & 22.05 & 0.063 & $0.000 * *$ & 0.018 & -0.620 \\
\hline $\mathrm{POC}^{\mathrm{T}}$ versus $\%$ of $1^{\text {st }}$ order river & 6.531 & -0.006 & $0.011^{*}$ & 0.006 & 0.165 \\
\hline POC $^{\mathrm{T}}$ versus dam density ${ }^{\mathrm{T}}$ & 4.664 & 0.051 & $0.032 *$ & 0.005 & -0.141 \\
\hline POC $^{\mathrm{T}}$ versus water area ${ }^{\mathrm{T}}$ & 3.514 & 0.032 & 0.061 & 0.002 & -0.147 \\
\hline
\end{tabular}




\begin{tabular}{|c|c|c|c|c|c|}
\hline POC $^{\mathrm{T}}$ versus Temperature & 2.717 & 0.009 & $0.010^{*}$ & 0.002 & -0.275 \\
\hline POC $^{\mathrm{T}}$ versus wetlands ${ }^{\mathrm{T}}$ & 0.667 & 0.011 & 0.414 & $<0.001$ & -0.182 \\
\hline POC $^{\mathrm{T}}$ versus soil organic matter ${ }^{\mathrm{T}}$ & 0.210 & -0.015 & 0.648 & $<0.001$ & -0.178 \\
\hline
\end{tabular}

${ }^{\mathrm{T}}$ indicated that variables are Log-transformed; *: $P<0.05 ;{ }^{* *}: P<0.01 \mathrm{Ad}-\mathrm{R}^{2}$ : adjusted coefficient of determination. 
Table 2. Interactive impacts of environmental variables on POC concentration over the U.S. and 18 water resource regions

\begin{tabular}{|c|c|c|c|c|c|c|c|c|c|c|c|c|c|c|c|c|}
\hline & $\mathrm{Tp}$ & Sd & $1 \mathrm{st}$ & $\mathrm{Sw}$ & $\mathrm{Tn}$ & Damd & $\mathrm{Om}$ & Wet & $\mathrm{T}$ & Area & $\mathrm{R}$ & Barr & Shrub & Clay & Urban & Ad- $R^{2}$ \\
\hline The U.S. & $\mathrm{P} * *$ & $\mathrm{P}^{* *}$ & $\mathrm{P}^{*}$ & $\mathrm{P}^{* *}$ & & $\mathrm{P}^{*}$ & & & & & & & & $\mathrm{~N}^{*}$ & $\mathrm{~N}^{* *}$ & 0.40 \\
\hline Region 1 & $\mathrm{P} * *$ & & & & & & & & & & & & & & $\mathrm{~N}^{*}$ & 0.59 \\
\hline Region 2 & $\mathrm{P} * *$ & & & & & & $\mathrm{P}^{*}$ & & & & & & & & & 0.64 \\
\hline Region 3 & $\mathrm{P}^{*}$ & & $\mathrm{P}^{*}$ & & & & & $\mathrm{P}^{*}$ & & & & & & & & 0.62 \\
\hline Region 4 & & & & & & & & & & & & & & & & NA \\
\hline Region 5 & $\mathrm{P}^{*}$ & & & & & & & & & & & & & & & 0.32 \\
\hline Region 6 & & & & & $\mathrm{P}^{*}$ & $\mathrm{P}^{*}$ & & & & & & & & & & 0.58 \\
\hline Region 7 & & & & & & & & & & & & & & $\mathrm{~N}^{*}$ & & 0.32 \\
\hline Region 8 & & $\mathrm{P}^{*}$ & & & & & $\mathrm{P}^{*}$ & & & & $\mathrm{~N}^{*}$ & & $\mathrm{~N}^{*}$ & & & 0.66 \\
\hline Region 9 & & & & & & & & & & & & & & & & 0.54 \\
\hline Region 10 & & $\mathrm{P}^{*}$ & & & & & & & & $\mathrm{P}^{*}$ & & & & & & 0.34 \\
\hline Region 11 & & & & & & & & & $\mathrm{P}^{*}$ & & & & $\mathrm{~N}^{*}$ & & $\mathrm{~N}^{*}$ & 0.40 \\
\hline Region 12 & & & & & & & & & & & & & & & & NA \\
\hline Region 13 & & & & & & & & & & & & & & & & 0.51 \\
\hline Region 14 & & & & & & & & & & & & & & & & NA \\
\hline Region 15 & & & & $\mathrm{P}^{*}$ & & & & & & & & & & & & 0.17 \\
\hline Region 16 & & & & & & & & & & & & & & & & NA \\
\hline Region 17 & $\mathrm{P}^{*}$ & & $\mathrm{P}^{*}$ & & & & & & & & & & & & & 0.75 \\
\hline Region 18 & & & & & $\mathrm{P}^{*}$ & & $\mathrm{~N}^{* *}$ & & & & & $\mathrm{~N}^{*}$ & & & & 0.59 \\
\hline
\end{tabular}

Om: soil organic matter; Wet: wetland area; T: temperature; R: runoff; Area: drainage area for each station; Barr: percentage of barren land; Urban: percentage of urban area; Shrub: percentage of shrub area; Crop: percentage of cropland; Clay: percentage of soil clay; Sw: soil water content; Sd soil bulk density; Slop: average slop of the drainage area; $1^{\text {st: }}$ percentage of first order watersheds; Tn: total nitrogen in waters; Tp: total phosphorus in waters; Damd: dam density. N: negative correlations; P: positive correlations; Ad-R ${ }^{2}$ : adjusted coefficient of determination; *: $P<0.05$; **: $P<0.01$. 
Table 3. Impacts of multiple environmental variables on POC concentration over different river orders

\begin{tabular}{|c|c|c|c|c|c|c|c|c|c|}
\hline & $\mathrm{Tp}$ & Damd & $\mathrm{Sd}$ & Wet & Sw & $\mathrm{Om}$ & Clay & $\mathrm{R}$ & ${\mathrm{Ad}-\mathrm{R}^{2}}^{2}$ \\
\hline Order 1-3 & & $\mathrm{P}^{*}$ & $\mathrm{P}^{*}$ & & & & & & 0.37 \\
\hline Order 4 & $\mathrm{P}^{*}$ & & & $\mathrm{P}^{*}$ & $\mathrm{P}^{*}$ & & & & 0.31 \\
\hline Order 5 & $\mathrm{P}^{*}$ & & & & & & & & 0.32 \\
\hline $\begin{array}{l}\text { Order } 6 \text { and } \\
\text { higher }\end{array}$ & $\mathrm{P}^{* *}$ & & & & & $\mathrm{P}^{*}$ & $\mathrm{~N}^{*}$ & $\mathrm{~N}^{*}$ & 0.50 \\
\hline
\end{tabular}

Om: soil organic matter; Wet: wetland area; R: runoff; Clay: percentage of soil clay; Sw: soil water content; Sd soil bulk density; Tp: total phosphorus in waters; Damd: dam density; N: negative correlations; P: positive correlations; Ad- $\mathrm{R}^{2}$ : adjusted coefficient of determination; *: $P<0.05 ; * *: P<0.01$. 


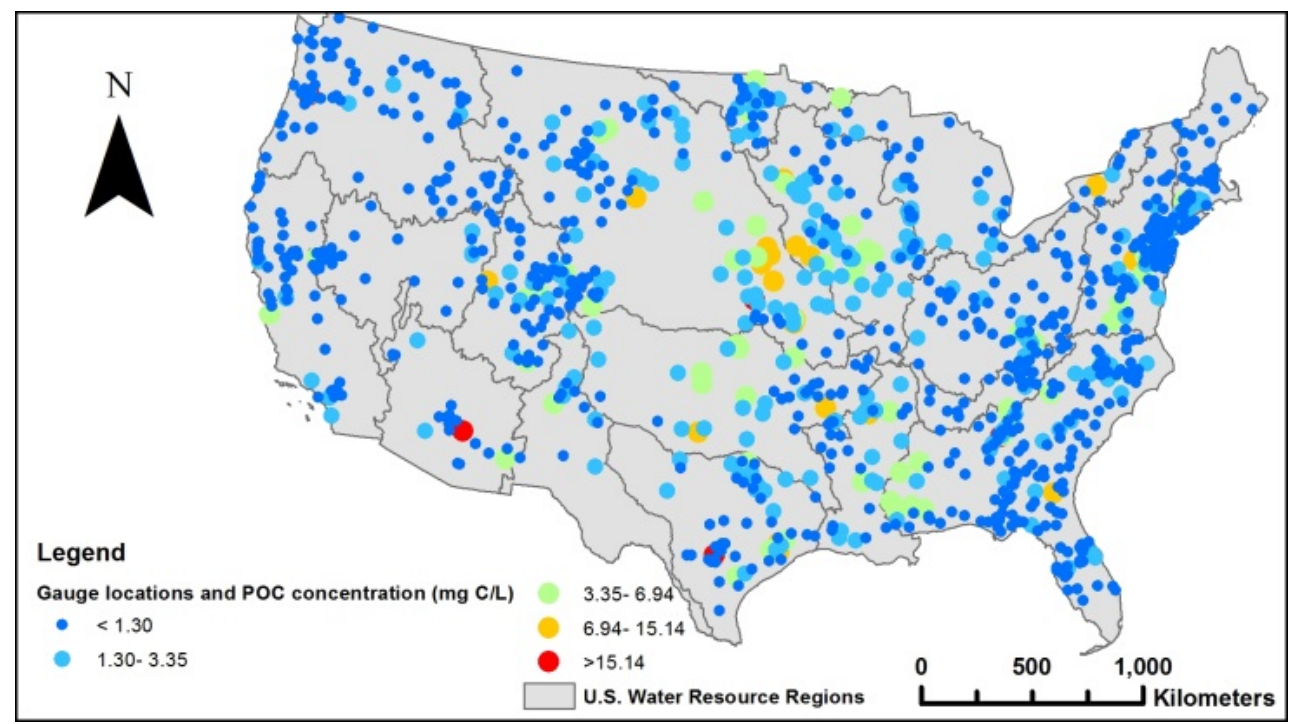

Figure 1. POC concentration at the 1145 U.S. Geological Survey gauge stations 


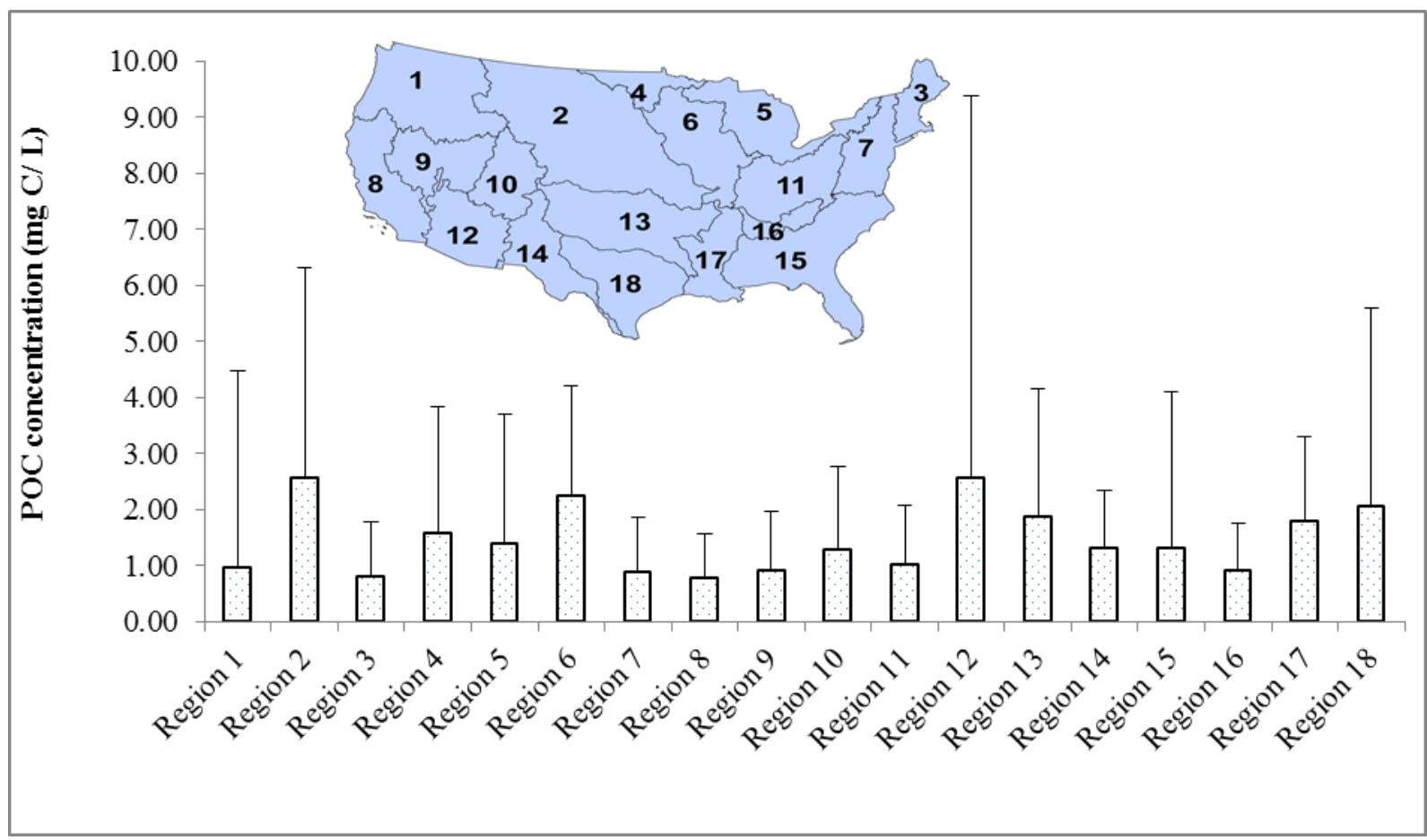

Figure 2. POC concentration in the 18 U.S. water resource regions (Region 1: Pacific

Northwest; Region 2: Missouri; Region 3: New England; Region 4: Souris-Red-Rainy;

Region 5: Great Lakes; Region 6: Upper Mississippi; Region 7: Mid-Atlantic; Region 8:

Region 12: Lower Colorado; Region 13: Arkansas-White-Red; Region 14: Rio Grande; 


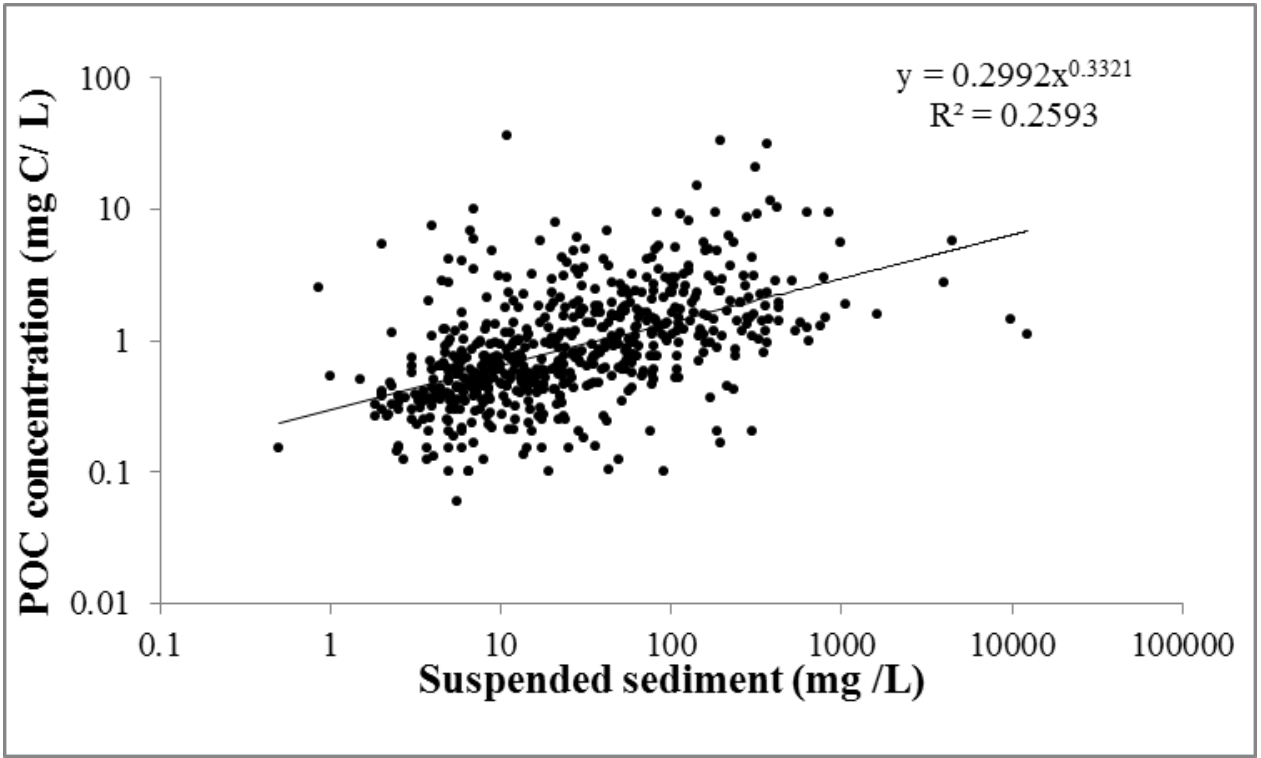

(A)

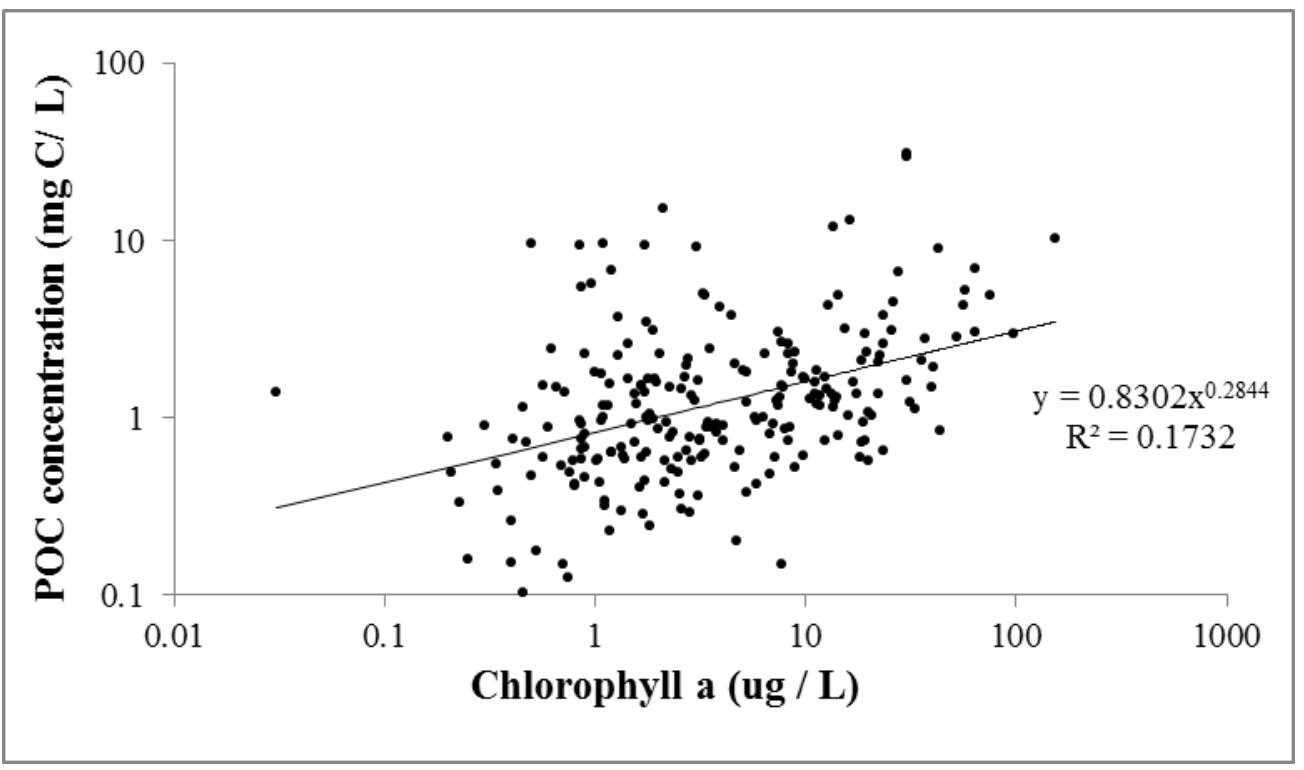

Figure 3. Linear regression between POC and suspended sediment (A) and between POC 


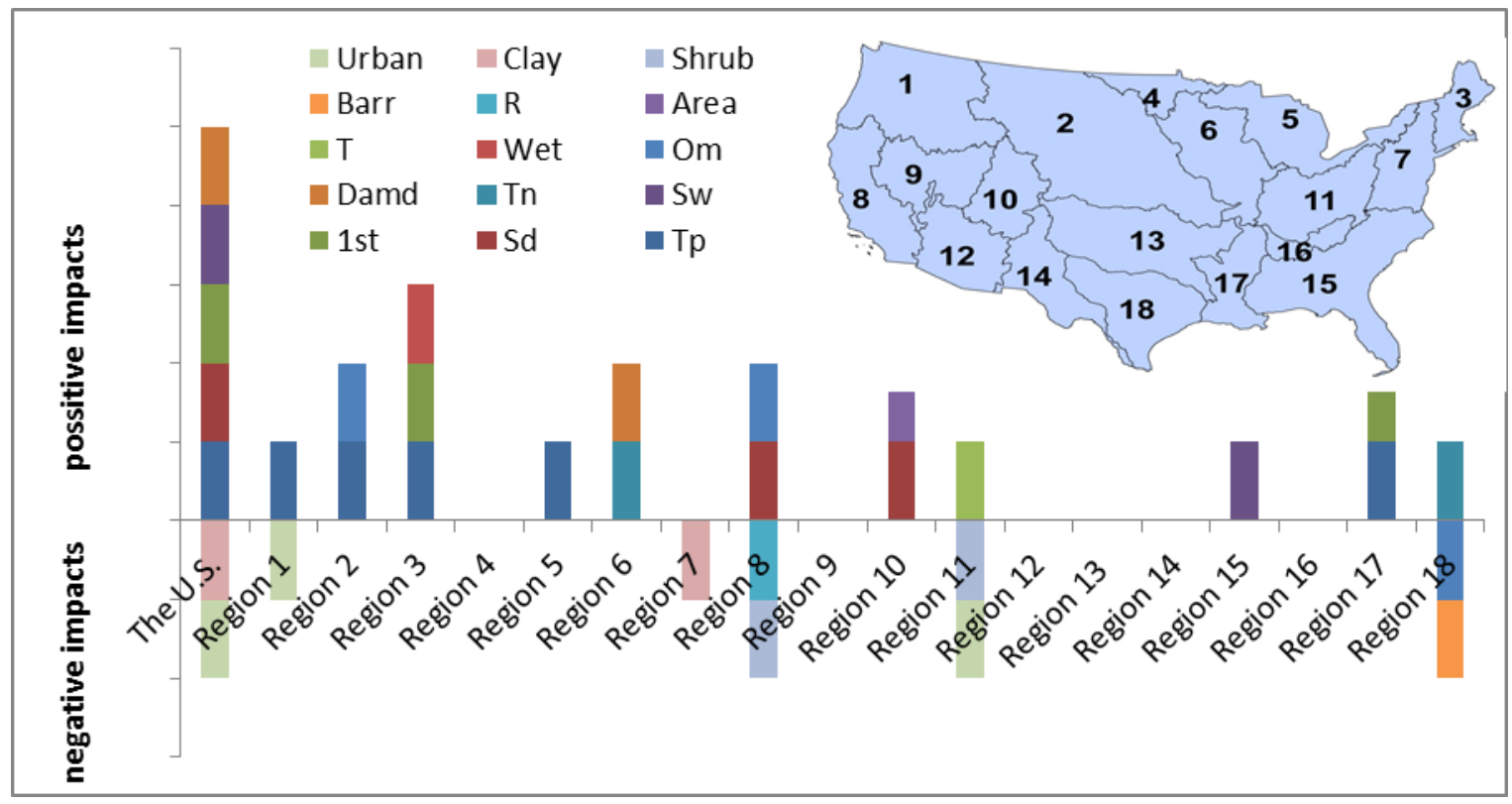

Figure 4. Factors with significant impacts on POC over the entire U.S. and the 18 water

43 resource regions (Om: soil organic matter; Wet: wetland area; T: temperature; R: runoff; Area:

44 drainage area for each station; Barr: percentage of barren land; Urban: percentage of urban area;

45 Shrub: percentage of shrub area; Crop: percentage of cropland; Clay: percentage of soil clay; Sw:

46 soil water content; Sd soil bulk density; Slop: average slop of the drainage area; $1^{\text {st. }}$ percentage

47 of first order watersheds; Tn: total nitrogen in waters; Tp: total phosphorus in waters; Damd: 


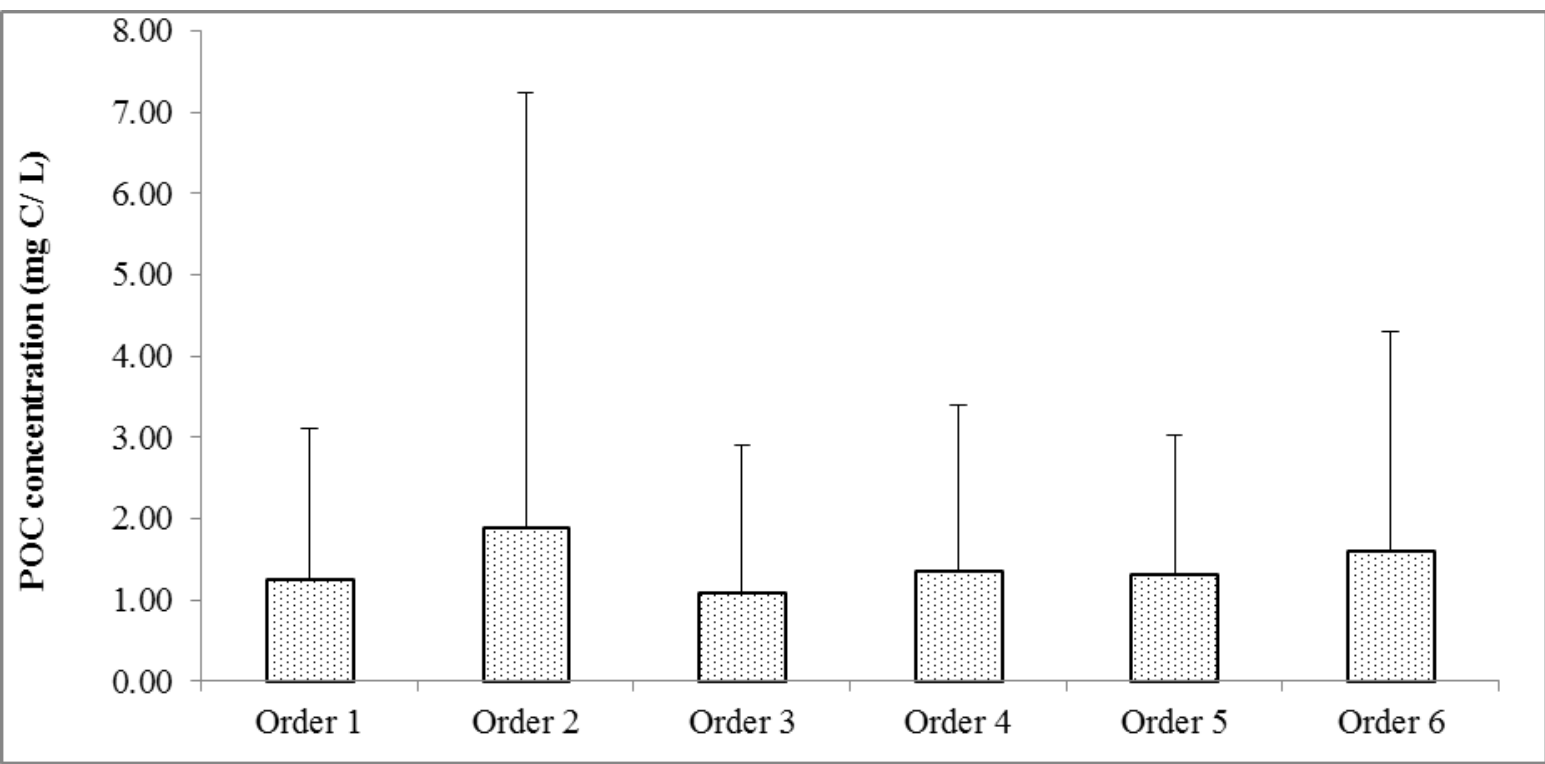

Figure 5. POC concentration by river orders 